\title{
THE TURKIC-SPEAKING PEOPLES OF THE FORMER U.S.S.R.(*)
}

\author{
- Prof. Dr. Türkkaya ATAÖV
}

\section{Introduction :}

The Turkic family of languages is the most numerous in the Soviet Union. The Turkic, Mongolic and Tungus-Manchu languages are sometimes grouped together as a single Altaic language. Taken together, they are at times referred to as Turanian Mongolic family as well. Sometimes, they are listed as independent language families.

In any case, I wish to dwcll here only on the Turkic languages in the former USSR. They include about 25 closely related dialects spoken by our northem neighbors. Those whose mother tongue is a Turkic language inhabit a vast territory extending from the Caucasus to the most eastern corners of Siberia. However, most of them live just across our border in the east, in the former Soviet Central Asia, the Volga region and parts of the vast arca generally called Siberia. There are a number of Turkic languages and dialects. All of them have a resemblance in one way or another to Turkish. Rather, Anatolian and Europcan Turkish is a derivative of Central Asian Turkish. Central Asia was "our" original homeland. This statement has no racist or expansionist pretensions. The dispersion of the Turkic - speaking peoples in a number of directions from the Central Asiatic mainland is a historical truth that Soviet scientific works do not contradict. There are many Russian and non-Russian Soviet publications that affirm this basic fact. This is a matter of cultural affinity; the Turkic languages have a common core. I have personally spoken with the Caucasians, Central Asians and other Turkic peoples living even near the Kamchatka Peninsula. I know that basically it is the same language. The extent of their relationship to the common core may vary in each case but a person who knows Turkish can understand many of the other varicties. The dialects may be loaded with Persian, Arabic and Russian words but the construction, the grammar and most of the vocabulary are either identical or similar.

If there are shades of difference, they should be explained on account of the historical experience of the various branches of the Turkic peoples. The scattering of the

${ }^{(*)}$ Submitted to the international seminar on "the Impact of Nascent Soviet Changes on Central Asia and the Region," 21-22 January 1992, Peshawar, Pakistan. 
Turks caused the emergence of several language groups and subgroups. Scholars of Turkic languages generally agree that there arc five broad groups. The first encompasses the languages of the Turkic peoples of the Caucasus, namcly the Azcrbaijani, Kumyk, Karachai-Balkar and the Nogai. Azcrbaijani is the language of the Azeri Turks of Transcaucasia. It belongs to the southwest Oghuz group of the Turkic division of the Altaic language family. It has four closely related dialect groups. The (eastem) Baku dialect forms the basis of the modern Azeri litcrary language. Now, the Azeris are toying with the idea of reverting to the Latin script first used between 1929 and 1939.

Kumyk language belongs to the Oghuz group of the Kypchak division of the Turkic language branch. As people they live in northern Daghestan (Caucasus). The Karachai-Balkar language also belongs to the Kipchak division. The Nogai are the descendants of the Turco-Mongolic nomads (the Golden Horde) that moved into the steps of north Caucasus. The language of the Turkmens of north Caucasus, who came from Turkmenia (Central Asia) should also be included in this first group. They live mainly in the Stavropol Territory.

The second group includes the languages of a number of Turkic peoples living in Central Asia and Kazakhstan: Uzbck, Turkmen, Kirghiz, Kazak, Karakalpak and Uigur. The Uzbek language belongs with Uigur to the Karluk (Chagatai) division of the Turkic branch. Turkmen belongs to the Oghuz division, and Kirghiz and Kazakh arc part of the Nogai group. Karakalpaks are bilingual (Karakalpak and Uzbck).

The third group consists of the languages of the Volga region and the Urals. They are spoken by the Tatars, Bashkirs and the Chuvash. The two are very close to each other. Tatar belongs to the Kipchak-Bolgar group of the Kipchak division of the Turkic branch. Bashkir has two dialects. Chuvash is a distinct group in the Turkic branch. Some linguists consider it a Hunnic language.

The fourth group includes the languages of those Turkic peoples who live in western Latvia, the Ukraine (including the Crimea) and in southern Moldavia. They are. the Gagauz, Crimean Tatars and Karaim. This group also includes the Urums (Greeks who have assimilated Turkish culture), the Krymchaks and the Lithuanian (and Byelorussian) Tatars. The Urums are a little over 100,000 persons, the Krymchaks are less than 2,000 and the last mentioned have their language. Only written evidence of the latter remains.

The fifth group consists of the languages of the Turkic peoples of Siberia: Yakut, Tuvinian; Altaic, Khakas, Shor and Chulym languages. The last two do not possess a written form. On account of historical development, large and small groups of Turkicspeaking peoples may be found almost in every part of the Soviet Union. But in some cases, they constitute the basic indigenous population within certain administrative units. For instance, the Azeris, Uzbeks, Kazakhs; Turkmens and Kirghiz made up the stock population of Union Republics that bore their names. Some, like the Bashkir and the Karakalpak, are administratively organized at a lower status. Each of these Turkic branches have specific historical, ethnographic, cultural and other characteristics which influenced the development of their languages. 


\section{Uzbek :}

The Uzbeks are the most numerous Turkic-speaking peoples in the former USSR, third in size after Russians and Ukrainians. Uzbekistan is in Soviet Central Asia betwen Amu Derya and Sir Derya Rivers, the Aral Sea and the slopes of the Tien Shan mountains. It has a population of 19.6 million of which 69 percent are Uzbcks, 11 percent Russians, 4 percent Tatars, 4 percent Kazakhs, 4 percent Tajiks, 2 percent Karakalpaks and 1 percent Koreans. The Uzbek SSR included the Karakalpak Autonomous SSR.

There were relatively large groups of Uzbeks living in other republics of the Sovict Union. Some of them also live abroad. The Uzbek language serves the Turkic Uzbek people, who constitute the largest nation in Central Asia. The language has long possessed a written form. It comprises a number of dialect groups: Karluk, Oghuz and Kipchak, each with sub-dialects. The dominant one is the Karluk (or Chagatai) group, spoken in the main urban centres. The central dialects, as a result of Iranian influence, have lost vowel harmony. The southern Karluk dialects still maintain it. The dialects around Khiva (Khwarezm) are basically Oghuzic (a result of Turkmen influence) with a strong Kipchak element.

The first literary Turkic language of Uzbckistan (pre-Uzbck) was based on a Kurluk dialect (10th-11th cent.). A new literary language, introduced later, was used until the 15th century, or until the arrival of the Uzbek invaders. This was based on the Oghuz language. Since the 15th century, the people of Uzbekistan used a Karluk dialect (Chagatai).

Although the language had a written form, before 1917 the masses were generally illiterate. The rich literature in old Uzbek was accessible to a small clitc. There were few literary persons and the general level of culture was low. There were no institutes of higher learning. There are now 31 such educational centers. In 1913, a year before the start of the First World War, only 37 books in Uzbek had been published. In the 1980s, the yearly average was about a thousand, with a total circulation of over 15 million.

The Uzbek language experienced significant changes. Until 1928 the Arabic script was used. It was changed to Latin and then (1940) to Cyrillic. Between 1922-29 various literary forms based on local dialects were employed. In 1929 the Kipchak dialect became the official literary Uzbek language. In 1934 it was replaced by the Tashkent (meaning "The City of Stone"in Turkish) dialect.

In the meantime, the vocabulary was enriched by an abundant stream of words (including Russian). The Uzbck language benefited from the contributions of leading writers from various ages. The names of Aini, Aibck, Gulyam and Kerbabayev were already known before 1945. Uzbek literature has been enriched by the works of gifted writers in recent decades: Rashidov, Sheikhzade, Kakhar, Uigun, Gairati, Safarov, Zulfia, Kaipbergenov, Yusufov...

\section{Kazakh :}

The Kazakh language was mainly spoken in the wide steppes of the Kazakh SSR. Kazahstan is a very large area. If it had been situated in Europe, it would have been the 
largest $(2,717,000 \mathrm{sq} . \mathrm{km}$.) country of that continent. Its population is 16.5 million, only 36 percent of which are Kazakhs. It is important to note that 41 percent are Russians and 6 percent Ukrainians. There are of course large groups of Kazakhs in other Soviet Republics, including 477,820 in Russia's: Federation, 476,310 in the Uzbek SSR, the rest residing in Turkmenia, Kirghizia and Tajikistan.

The Kazakhs are ethnically, culturally and linguistically related to the Kirghiz and Karakalpaks. Sometimes, they are considered as a division of a Kirghiz pcople. Formerly, the pastoral Kazakhs were divided into three territorial groups (hordes): Elder, Central and Younger.

The Kazakhs were converted to Islam prinarily under the influence of the Tatars. This was supported by the Russian Tsars who preferred the Kazakhs to be supported by the Tatars rather than the anti-Russian and much more conservative Central Asiatic Turkic peoples, Almost the total (98 percent) of the Kazakhs consider the Kazakh language to be their mother tongue. Kazakh belongs to the Nogai group of the Kipchak division of the Turkic branch. Kazakh has three dialects which correspond to three hordes. The Kazakh literary language was based on the Central dialect which used the Arabic script. It was changed to the Latin script in 1929 and to Cyrillic in 1938.

\section{Azerbaijani :}

Azerbaijani is the language of the native peoples of Azerbaijan. The Union Republic had a population of 6,9 million pcople, of which 78 percent were Azcris, 8 percent Russians and 8 percent Armenians. In turn, 5 percent were Azeris in the Armenian SSR.

There were Azeris who lived in the other Union Republics. Beyond the boundaries of the USSR, they were found primarily in the ncighboring territory of Iran. In the 1926 census, the Azerbaijanis appear as "Turks" (Tyurki). They are predominantly Shiite Moslem in religion, with a significant Sunni Moslem minority. In the 1950s, the Meshketians, formerly classificd as "Turks", were reclassified (in the 1950s) as Azerbaijanis. Their places having been changed. It is unclear under what designation the Meshketians are listed in later censuses. In 1979 a group appeared under the designation "Turki"; these were probably Meshketians who declared themselves Turks.

The Azeri language belongs to the southwest Oghuz group of the Turkic division. It is very similar to Anatolian Turkish. Before 1917 the Azeri literary language found only limited use since the vast majority of the population was illiterate. Limitations of the Arabic alphabet, spelling and terminology constituted the principle obstacle to the development of the Azerbaijani national culture and education. Until 1929 Azeri was written in the Arabic script (being virtually the same written language as Ottoman Turkish), at which time it was changed to Latin, and in 1939 to Cyrillic.

The basic vocabulary of the Azeri language is made up of original Azeri (Turkish) words that were widely employed by such carly classical writers as Nasimi, Khatai, Fuzuli and Vakif. Arabic and Persian words may be explained by the historical link between them and their neighbors. But as the literary language developed, native Azeri words replaced foreign terms. At the same time the Azcri terminology has becn enriched by a large number of international terms that are adopted together with new concepts that 
accompany the new life. The Latin script will probably be employed henceforth, bringing Azeri even closer to modern Turkish.

\section{Turkmen :}

The Turkmen language is the language of the basic native nationality of Turkmenistan in Central Asia. The former Union Republic's population was 3,5 million, of which 68 percent were Turkmen, 13 percent Russians and 9 percent (Turkic) Uzbcks. Turkmens also lived in the regions of Khorezm, Bukhara and Surkhan Darya, in the Karakalpak ASSR of Uzbckistan and in the Russian Federation (Stavropol), in the north of Daghestan and in the Dzhilikul Region of the Tajik SSR. Close to a million Turkmens live in Afghanistan, Iran, Turkey, Iraq, Syria and China.

They are the descendants of the early Oghuz Turks. Although culturally related to the other people of Central Asia, linguistically they are closer to the Azeris. They are divided into major territorial-tribal groups, cach of which has a dialect. The main Turkmen tribes are the: Teke (who alone account for 35 percent of the total Turkmen population, Tamut, Ersari, Salur, Saryk, Goklen, Chudor, Alili, Karadash (Black) stone) and Emreli.

Their language belongs to the Oghuz division of the Turkic branch. In the 18th century rich litcrature was alrcady being published in the Turkmen language. The works of Makhtumkuli were mainly responsible for the establishment of literary standards. Until 1917, however, the Turkmen literary language was not widely read. The proportion of the illiterate was too great. The objective processes of consolidation and development of the Turkmen nation have resulted in an increase in the role of the literary language in the life of the people as well as in reduction of differences among dialects.

The written form was originally based on the Arabic script. It was changed to Latin (1928) and then to Cyrillic (1940).

\section{Kirghiz :}

The Kirghiz language is employed by the Kirghiz who formed 48 percent of the people of the Kirghiz SSR (total:4.2 million), 26 percent are Russians and 12 percent Uzbcks. Some of the Kirghiz also lived in four other Union Republics. A few hundred thousand lived outside the USSR - in the Sinkiang-Uigur Autonomous Region (formerly referred to as "Chinese Turkestan" of the People's Republic of China, in the western regions of the People's Republic of Mongolia and in the northcastern parts of Afghanistan and Pakistan.

Scholars consider the Kirghiz to be one of the most ancient peoples of Central Asia. In terms of their origin, they are related, not only with the peoples of Central Asia and Kazakhstan, but also with the tribes of Sinkiang,

They were first mentioned in sources that date back to 201 B.C. Linguistically and culturally they are closely related to the Kazakhs and to a lesser degree the Karakalpaks. They have often been confused with the Kazakhs. Before 1917 they were called Karakirghiz. They then formed a nationality divided into separate tribes. In Soviet times they were unificd into a nation. 
Kirghiz belongs to the Nogai group of the Kypchak division of the Turkic branch. Because of past divisions into separate tribal groups, the Kirghiz language was also divided into numerous sub-dialccis. From a historical point of view it is customary to distinguish three stages in the development of the language: Ancient, Middle and New Kirghiz (from the 15th century). The first Kirghiz alphabet (1924) was based on 25 Arabic letters. It was changed to Latin (1928) and then (1940) to Cyrillic.

As a language with a recently acquired written form, the Kirghiz language provides an illustration of the rapidity with which a language may develop when its bearers experience a leap forward in their social progress. The social functions of the Kirghiz language have widened considerably since the 1920s. While formerly the dialects served relatively narrow spheres of life and primitive forms of production, today it is cmployed in the life of a modernizing nation.

A major role in the flourishing of a languatic that only recently acquired a written form is played by fiction. In this context it is important to note the rapid growth of a writers organization in Kirghizia and the appcarance of many gifted authors, including Chenghiz Aitmatov. There are 85 members in the Kirghiz Writers Union at the present time.

\section{Tatar :}

The Tatar language was employed in many republics and regions of the former Sovict Union. The Tatars are the descendants of various Kipchak - spcaking tribes that migrated westward from southern Sibcria in the 10th-13th centuries. Those groups that maintained dialects of Kipchal: (the Turkic branch of the Ural - Altaic language family) and who adopted Sunni Islam bccame known as Talars.

The term Tatar in the Soviet period was mistukenly applied to many non - Tataric people as well. It was used in the general linguistic sense to designate various Turkic people and in a religious sense to describe Moslem people and even sometimes in an cthno - racial sense to refer to people that appeared "oriental". Thus, such people as the Azeris, Balkars and a number of Sibcrians wcre erroncously called Tatars.

By the 16th century the term Tatar became basically synonymous with the Golden Horde and its various branches and territorial divisions (Kazan, Crimcan, Nogai and West Siberian). The Tatar people are composed of several groups. There are the Kazan Tatars (the largest and the most important around the Volga), Crimean Tatars (who were deported to Central Asia in 1944), Nogai Tatars of Astrakhan (including the Kundrov and Karagash), West Sibcrian Tatars (Tara, Baraba, Tobol, Tom, Tyumen, Tobolsk), Lithuanian, Kara and Glazov Tatars.

Under the influence of the Eastern Orthodox Church of Kazan a number of Tatars converted to Eastern Orthodox. They became known as Kryashen (Christianized) Tatars. Until the late 1930s the Kryashen had their own literary language which used the Cyrillic script. There were also a group of Mordvinians (Meshchera) assimilated by the Tatars (Mishars). Both of these were considered distinct ethnic groups until the 1930s when they were classificd as Tatars. 
The classical writers used the Kazan dialect and wrote in the Arabic script. The Crimean Tatars had their own literary language until their deportation (1944).

The Tatar language was already formed centuries ago under the Kazan Khanate. Its literary tradition is represented by the age-old works of such Tatar poets as Muhamedyar, Kuli, Imeni, Salikhov and Kandali. Tatar was one of the oldest literary languages in the USSR.

The literary language matured with the growth of the Tatar middle class (after the 1850s). A new stage began after 1917. Tatar literary language became accessible to all layers of the population. It is in this period that it prevailed over individual dialects. Rich fiction works and poetry camc into the Soviet pcriod, including the immortal works of Musa Djalil. Some publishing of Crimean Tatar was also seen since the 1960s. The Cyrillic alphabet (1940) has replaced Latin (1928).

\section{Chuvash :}

The Chuvash language is employed by the Chuvash nation. They are the descendants of Volga Bolgars. Of the total 1,175,366 Chuvash population, about one half lived on the territory of the Chuvash ASSR. They are divided into two ethnographic groups, which correspond to the major dialect divisions: Viryal (upper) and Anatri (lower) Chuvash. The Chuvash language forms a distinct group in the Turkic branch. Its literary version is based on the Anatri dialect.The language of the Chuvash was based on the Russian script (1873) mainly because the Chuvash are Eastem Orthodox in religion. Interest in that language increased particularly after the founding of the University of Kazan, which had become a center of the study of many Turkic tongues. Professor N.I. Ashmarin, the leading specialist on this topic, is the author of a monumental 17 volume dictionary ot the Chuvash language.

\section{Bashkir :}

The Bashkir ethnic group was formed on the basis of a number of Turkic tribes: Kipchak, Kanly, Min, Kirghiz and others. Of the total 1,371,452 people, most of them (75 percent) lived on the territory of the Bashkir ASSR. Small groups of Sahkirs were also found in several other regions, such as the Tatar ASSR, Orenburg, Kurgan and Chelyabinsk Oblasts.

The Bashkir language is one of the languages that has recently acquired a written form. It was developed during the Soviet period. Shortly after the proclamation of Soviet authority in Bashkiria, the question of creating a Bashkir national language assumed a leading place. In 1918 a high - level mecting of Bashkirs and Tatars considered the issue, creating in the meantime a. Central Commission and resolving organizational problems related to the training of national personnel, the establishment of publishing houses and a national theater. An ad hoc commission elaborated a Latin written form in 1923, changed to Cyrillic in 1940.

The Bashkir language belongs to the Kipchak division of the Turkic branch. It is very close to Tatar. In the last census (1979) about a third of the Bashkirs declared Tatar their native tongue. The Bashkirs are Sunni Moslem. Among them there is a small minority of Eastern Orthodox Christians, the Nagaibak. 


\section{Yakut :}

The Yakut language is employed over a vast territory in the northeastem part of Siberia. Their total population was 328,018 in 1979. Their language belongs to the old Uigur group of the Eastern division of the Turkic branch. The dominant theory on their origin was that they were a group of Turkic-speaking people from around the region of Lake Baikal who were forced to move northward by the ancestors of the Mongolic Buryats in the 13th century. Yakut serves as a lingua franca for some of the surrounding. people such as the Dolgans, Yukargirs, Evenks and Evens.

The Yakutyan should not be confused with the Yakuts. The former are a group of Russians who lived along the Lena River, mixed with local Yakuts and adoptcd the Yakut culture but kept the Russian identity and language. They are considered Russians. Another group of Russians setiled along the Kolyma River where they mixed with local Yakuts. They are called Kolymchan and unlike the Yakutyan, they gave up the Russian language and culture and became totally Yakutized. But they are still classified as Russians.

The Yakut language holds a special place among the other Turkic languages. It is archaic in character, having preserved many clements of the ancient Turkish languages. Most words are still of Turkic origin. Words borrowed during the Soviet period derive primarily from the press, radio and television and retain their specific features. The alphabet was Latin (1929), later changed to Cyrillic (1939). The religion of the Yakuts is a mixture of Eastern Orthodox and shamanist - animist belicfs.

\section{Karakalpak :}

Karakalpak is the language of the Karakalpak nationality, which constitutes 31 percent of the population of the autonomous republic in Uzbckistan bearing that name. "Karakalpak" in Turkish means "Black Fur Cap" (Russian: Chyorniye Klobuki). The people are related linguistically and culturally to the Kazakhs and the Kirghiz. There were about 320,000 Soviet Karakalpaks. In addition, the Karakalpaks also live in the Khorezm and the Ferghana regions of Uzbckistan, the Tashauz region of Turkmenia, the Astrakhan region of the Russian Federation and several areas of Kazakhstan. They are Sunni Moslem in religion and are under strong Uzbek influence.

Karakalpak, the language, belongs to the Nogai group of the Kipchak division of the Turkic branch. It took shape in the Kipchak tribes which formed unions first with the Golden Horde and later with the Great Nogai Horde. A local variant of the common Central Asian litcrary language called "Turki" existed in Karakalpakia already before 1917. But, because of the very low rate of literacy, its significance was reduced to a minimum. It was during the Soviet period that the problems of a written form and of a literary language were resolved. In 1924 a reformed Arabic alphabet was adopted. We know from our experience in Turkey that the Arabic script does not serve a Turkic language well. It was replaced by Latin (1928) and then by Cyrillic (1940. 


\section{Kumyk :}

The Kumyk language served the Turkic-speaking nationality of the Daghestan ASSR. They are Sunni Moslem, with some Shiite Moslems in Derbent and Mohachkale. They live primarily on the northern steppes of Daghestan. Even though numerically small $(300,000)$, their cultural, linguistic, political and economic influence was great. Kumyk served as a lingua franca for all eastern North Caucasians. Different views exist concerning the origin of the term "Kumyk". One interpretation is that it comes from the Turkish word "Kum" meaning "sand".

The Kumyk language belongs to the Oghuz group of the Kipchak division of the Turkic branch. It has three closcly related dialects - Khasavyurt, Buinak and Kaitak. A written tradition has existed since the last century. Individual works of fiction also appeared. One may citc the "Collection of Nogai and Kumyk Pocms" by Osmanzadeh, printed in St. Petersburg (1883). But the development of the Kumyk literary language occurred after 1917. At first the written form was based on Arabic, but because that script poorly reflecied the traits of the Kumyk phonetic system, it was replaced by Latin (1929) and later by Russian characters (1938).

\section{Karachai - Balkar :}

The Karachai - Balkar language scrves two pcoples, the Karachais and the Balkars. They are descendants of a mixlure of peoples, mainly the Kipchak Turks. They are both Sunni Moslem in religion. Together they are about 200,000. They were deported to Central Asia in 1944, where thcy remained until 1959. The Karachai formerly lived in the mountainous southern region of the Karachai - Cherkess AO but since their return to the region they have been resettled in the foothills of that territory. The Balkar lived in the Kabardino - Balkar ASSR, but since their return have lived in the foothills of the same region.

In the remote past they possessed common ancestors. This is indicated by their common language, which is a remnant of the Turkic tribe that gave its name to the Alan union of tribes. The beginnings of the formation of a literary language coincide with Sovict power in the north Caucasus and with the appearance of the works of Kazimov, Kuliyev and others. Because of the absence of a written form before 1917, researchers studicd only the traditions and the dialects. The Karachai - Balkar language was first (1924) written in Latin and then in Cyrillic (1939).

\section{Nogai :}

The Nogai language is spoken mainly in the Stavropol Territory and in the Karachai - Cherkess Autonomous Region. There are also individual groups elsewhere. The Nogai are the descendants of the Turco-Mongoloid nomads that moved into the steppes of north Caucasia. They represent a relatively small remnant of a once more powerful and numerous people. In the pre-Soviet period, the Nogai were being assimilated by the Circassians (in the west) and by the Kumyks (in the east). The Nogai of the Crimea and Romania were assimilated by the Crimean Tatars and those of Astrakhan by the Astrakhan Tatars. As a result of continuous pressure form Russian scttlers in north Caucasia, there was a stcady migration of Nogai to Turkey, the Crimea and Romania (Dobrugea). The majority emigrated to Turkey in the mid 1860s. The 
Nogai are Sunni Moslem in religion. Their language belongs to the Kipchak - Nogai group of the Turkic branch. Two Nogai literary languages were established in 1928: Ak (White) and Kara (Black) Nogai. Only an insignificant part of the Nogais were litcrate before 1917. Their written language was the North Caucasian version of "Turki." Initially they used Latin, but since 1938 they have used the Russian alphabet.

\section{Tuvinian :}

The Tuvinian language was spoken by most inhabitans of the Tuva ASSR in south-central Siberia. There were 166,082 Tuvins in the USSR. They are of mixed origin, but are mainly Turkic - Mongols. Although the Tuvinian territory was a "client state $^{*}$ of the Soviet Union since 1921, it was formally incorporated in 1944. Some Tuvins are assimilated by other Sibcrian peoples. Their language belongs to the old Uigur group of the Eastern division of the Turkic branch.

It has retained a number of archaic traits that make it akin to Ancient Oghuz and Ancient Uigur Turkic languages. Before the Soviets the language did not have a written form. In 1930 they used Latin, but changed to Cyrillic (1943).

\section{Uigur :}

The Uigur language belongs (with Uzbck) to the Karluk division of the Turkic branch. The greater part (some four million) of the Uigurs live in the Uigur Autonomous District (Sinkiang Province) of the P.R. of China. The Soviet Uigurs lived primarily in south-eastern Kazakhstan, eastern Uzbckistan (especially around Andizhan) and in the main cities of Kirghizia. The word "Uigur" has been known since the times of the ancient Turkish inscriptions on the Orhon River and from Chinese sources. That name vanished for a long time, but they wcre selt - designated as Uigur since 1921.

They are also known according to place of origin or mode of livelihood: Kashgarlik (from Kashgar), Turpanlik (from Turpan), Aksuluk (from Aksu) of Tranchi ("farmer" in Uigur). The Soviet Uigurs were the descendants of the Uigur migrants from Chinese Turkestan. They migrated to Central Asia but maintaincd place names of origin. In the early and mid - 20th century there were two minor waves of immigration from Chinese Turkestan.

They had a literary language already in the 10th century during the Karakhanid State. It was reflected in the works of Uigur poets and writers such as Khirkiti, Novbati, Zelili, Nizari, Shakir and Bilala. The modern Uigur literary language dates back only to 1946. The literary Uigur language in China is based on the southern dialect and uses the Latin (formerly Arabic) script. The Uigurs are Sunni Moslem. The marked decline in the Soviet Uigur population was the result of the assimilation of many Fergana Uigurs by the Uzbeks.

\section{Khakas :}

The Khakas language is spoken along the midstream area of the Yeniscy River. Ninety percent of them live in the Khakas Autonomous Region in southern central Siberia. Before 1917 they did not have a common name. They were divided into five 
territorial groupings. They are a very small group $(75,000)$ but they are among the most ethnically complecx peoples.

Their dominant language is Kacha, which belongs to the Uigur group of the Eastern division of the Turkic branch. They used first Cyrillic(1924), then Latin (192838) and Cyrillic again. Their rcligion is a mixture of shamanist - animist and Eastern Orthodox bclicfs.

\section{Altaic :}

The Altaic language serves the native inhibitans of the Gorno - Altai Autonomous Region in the Russian Federation. They live primarily in Western Siberia. Although they are a small people (slightly above 60,000 ), there are two groups of Altais: Southern and Northem. They include a number of peoples which have evolved from an ancient Turkic ethnic base. In the pre-Sovict period each of these tribal - territorial groups was considered a distinct people with its own dialect. The Altai language still has two dialects belonging to different divisions of the Turkic branch.

The written form was first created by missionaries in the 1840s and was based on the Telcut dialect. But books published at that time were primarily of a religious character.

The religion of the Altai is a mixture of shamanist - animist and Eastern Orthodox beliefs: After the Revolution a literary language became a common language for all. The alphabet was first Cyrillic (1923-28), then Latin (1928-38) and Cyrillic again.

\section{Gagauz :}

The Gagauz is a Turkish dialect with many Slavic additions. The Gagauz as people $(180,000)$ are Christianized (Eastern Orthodox) Turks who migrated to Bessarabia (Moldavia) in the late 18 th and early 19 th centuries.

Their language belongs to the Oghuz division of the Turkic branch. In the inter war period, Moldavia was pant of Romania, and therefore, the 1926 Soviet census reflects only those living outside Moldavia (primarily, in adjacent areas in the Ukraine).

As far as the USSR is concerned, the Gagauz language was spoken in the southem regions of Moldavian SSR, and in adjacent areas of the Odessa Region in the Ukrainian SSR. Individual Gagauz villages are also found in Kazakhstan and in Central Asia (since 1910). There are Gagauz minorities in Romania and in Bulgaria. A leading Romanian Gagauz is Professor M. Gupoghlu, an acknowledged authority on Ottoman history. Foreign Turkologists consider Gagauz as a Turkish dialect.

Attempts to create a written form of the Gagauz language were undertaken between 1910 and 1930. In particular the Kishinev diocese published books translated by the Gagauz priest $M$. Chakira first on the basis of the Russian alphabet and then of the Romanian alphabet. It was only in 1957, following a decree of the Presidium of the Supreme Soviet of the Moldavian SSR, that the written form of the Gagauz language was introduced. 


\section{Conclusion :}

These are the basic languages in the Turkic: family, spoken in the former USSR. They include a number of other languages or dialects. Taken together, they make up the second place there after the Slavic languages. And the people who speak Turkic languages inhabit a vast area from the Caucasus to parts of Sibcria. One or the other Turkic dialect is predominant in the whole of Central Asia and Kazakstan. There is also a genetic kinship between the Turkic and the Mongolian and Tungus - Manchurian languages, on which I have not dwelled here. 